\title{
Perkembangan Desa Wisata Pangsan Sebagai Destinasi Pariwisata Di Kecamatan Petang Badung
}

Ni Luh Laksmi Parashitaa, 1, I Made Adikampana a, 2

1hitalaksmi@gmail.com,2adikampana@unud.ac.id

a Program Studi S1 Destinasi Pariwisata, Fakultas Pariwisata,Universitas Udayana, Jl. Dr. R. Goris, Denpasar, Bali 80232 Indonesia

\section{Abstract}

This report, entitled "Development of Pangsan Village Tourism as Destinations in Petang District of Badung Regency" with the background of the issue stating that the tourist village near death, or it can be said as a tourist village that did not develop. This study aims to determine the involvement of what has been made public for five years after the enactment of a tourist village and how the development of village tourism with the involvement of the community as the manager of the tourist village through analysis of the Destinations Lifecycle Theory.

Judging from Destinations Lifecycle theory, Pangsan Village Tourism stage of development at the stage of Involvement / participation is increasing visitors encouraged local residents offers exclusively to its visitors. Contact with local peduduk remain high and some of them began to adjust their social patterns to accommodate changes in economic conditions due to the presence of tourists. Promotion of tourist destinations ranging initiated. During the process of collecting the data, obtained by the findings that the involvement or participation in a tourist village in the management of member services, guides, to provide lodging for travelers when visiting tourist village. In addition, people began to provide other facilities such as trekking and cycling facilities as well as the efforts rafting prepared by one of the people.

Keywords: Tourism Village, Involvement, Development

\section{PENDAHULUAN}

Perkembangan pariwisata di Kabupaten Badung yang mengarah pada kegiatan pariwisata massal/ mass tourism yang mana penyelenggaraannya melibatkan wisatawan dengan kapasitas yang besar atau berombongan. Mass tourism di Badung cenderung terlihat di daerah Badung selatan seperti Seminyak, Kuta, Jimbaran, dan Nusa Dua dengan kepadatan kedatangan wisatawan setiap harinya. Hal tersebut dipengaruhi oleh semakin berkembangnya penawaran wisata yang ditawarkan dengan fasilitas yang lengkap sehingga dapat menarik kedatangan wisatawan ke suatu daerah serta didukung oleh adanya travel agent dengan menawarkat paket tour yang lebih memprioritaskan ke destinasi di Badung selatan yang semakin padat. Kegiatan alternative tourism dikembangkan untuk dapat memberikan manfaat pada masyarakat yang memiliki potensi di masing-masing daerah melalui partisipasi dalam penyelenggaraan kegiatan pariwisata. Salah satu kegiatan alternative tourism yang sedang dikembangkan oleh pemerintah yaitu desa wisata. Desa wisata sebagai wilayah pelestarian alam lingkungan ekosistem serta simpul budaya tradisional masyarakat dengan tidak menghambat perkembangan warganya untuk meningkatkan kesejahteraan hidupnya melalui usaha. Suatu desa wisata harus terus dan secara kreatif mengembangkan identitas atau ciri khas daerah.

Berdasarkan Peraturan Bupati Badung Nomor 47 Tahun 2010 Tentang Penetapan Desa Wisata di Kabupaten menetapkan 11 kawasan desa wisata, diantaranya Desa Petang, Desa Pelaga, Desa Pangsan, Desa Belok, Desa Carangsari, Desa Bongkasa, Desa Sangeh, Desa Mengwi, Desa Baha, Desa Kapal, dan Desa Munggu.

Dari beberapa desa ditetapkan sebagai desa wisata di Kabupaten Badung, salah satunya yaitu Desa Wisata Pangsan. Desa Wisata Pangsan telah dikelola oleh masyarakat lokal, namun Desa Wisata Pangsan sangat sepi pengunjung setelah ditetapkan sebagai Desa Wisata oleh Pemerintah Kabupaten Badung, sehingga muncul sebuah isu yang mengatakan bahwa Desa Wisata Pangsan merupakan "Desa Wisata Mati Suri" (Denpost News, 2013). Adanya isu tersebut disebabkan karena pertumbuhan kunjungan yang lamban pertahunnya. Oleh karena itu, perlu adanya penelitian untuk mengetahui perkembangan Desa Wisata Pangsan sebagai salah satu desa wisata di Kecamatan Petang yang pengelolaannya secara langsung oleh masyarakat serta dapat mengetahui keterlibatan atau partisipasi apa saja yang telah dilakukan masyarakat untuk dapat mendatangkan wisatawan ke daerah tempat tinggal mereka. Dari uraian latar belakang 
diatas dapat dirumuskan rumusan masalah yaitu, bagaimana perkembangan Desa Wisata Pangsan dengan adanya partisipasi oleh masyarakat lokal yang bertujuan untuk mengetahui perkembangan Desa Wisata Pangsan dengan adanya partisipasi oleh masyarakat lokal setalah ditetapkan sebagai salah satu desa wisata di Kabupateb Badung.

\section{TINJAUAN PUSTAKA}

1. Konsep Desa Wisata

Desa Wisata merupakan suatu bentuk integrasi antara interaksi, akomodasi, dan fasilitas pendukung yang disajikan dalam struktur kehidupan masyarakat yang menyatu dengan tata cara dan tradisi yang berlaku, (Nuryanti, Wiedu 1993).

2. Teori Siklus Hidup Destinasi (Destination Lifecycle Model)

Menurut Richardson dan Fluker,2004 siklus hidup destinasi (Destination Lifecycle Model) merupakan model yang menjadi ciri khas setiap tahap dalam siklus hidup destinasi (daerah tujuan dan daerah resor) terdiri dari pengenalan, pertumbuhan, kedewasaan, dan penurunan dan / atau peremajaan. Tujuan tersebut ialah mengetahui evolusi atau perubahan dari produk dan destinasi pariwisata. Salah satu model siklus hidup destinasi dari Butler yaitu:

1. Exploration/Eksplorasi

Kunjungan terbatas dan sporadic dari orang yang ingin berpetualang. Terjadi kontak yang intensif dengan penduduk lokal dan menggunakan fasilitas yang dimiliki penduduk dengan dampak social dan ekonomi yang sangat kecil.

2. Involvement/ Keterlibatan

Meningkatnya pengunjung yang mendorong penduduk lokal menawarkan fasilitas secara ekslusif kepada pengujung. Kontak dengan penduduk lokal tetap tinggi dan beberapa dari mereka mulai menyesuaikan pola sosialnya untuk mengakomodasi perubahan kondisi ekonomi akibat keberadaan wisatawan. Promosi destinasi wisata mulai diinisiasi.

\section{Development/Pengembangan}

Investor luar mulai tertarik untuk menanamkan modalnya guna membangun berbagai fasilitas pariwisata di destinasi tersebut seiring dengan berkembangnya pemasaran destinasi. Aksesibilitas mengalami perbaikan, advertising semakin intensif dan fasilitas lokal mulai diisi dengan fasilitas modern dan terbaru. Hasilnya adalah menurunnya partisipasi dan kontorl oleh penduduk lokal. Atraksi buatan mulai muncul, khusus diperuntukan untuk wisatawan. Tenaga kerja dan fasilitas import mulai dibutuhkan untuk mengantisipasi pertumbuhan pariwisata yang begitu cepat.

4. Consolidation/Konsolidasi/ Penguatan

Porsi terbesar dari ekonomi lokal berhubungan dan bersumber dari pariwisata. Level kunjungan tetap meningkat namun dengan rata-rata kenaikan yang semakin menurun. Usaha pemasaran semakin diperluas untuk menarik wisatawan yang bertempat tinggal semakin jauh dari sebelumnya. Fasilitas yang sudah tua sekarang menjadi ketinggalan zaman dan kurang diminati.

\section{Stagnation/Stagnasi}

Kapasitas maksimal dari factor penunjang telah mencapai batas maksimum atau terlampaui, menyebabkan masalah ekonomi, social, dan lingkungan. Jumlah puncak kunjungan wisata tercapai. Atraksi buatan menggantikan atraksi alam dan budaya, serta destinasi tidak lagi dianggap menarik.

\section{Post-Stagnation/ Pasca Stagnasi}

Decline/ Menurun ialah Wisatawan tertarik dengan destinasi lain yang baru. Fasilitas pariwisata digantikan oleh fasilitas non pariwisata. Atraksi wisata menjadi semakin kurang menarik dan fasilitas pariwisata menjadi kurang bermanfaat. Keterlibatan masyarakat lokal mungkin meningkat seiring penurunan harga fasilitas pariwisata dan penurunan pasar wisatawan. Daerah destinasi menjadi terdegradasi kualitasnya, kumuh, dan fasilitasnya tidak berfungsi sebagaimana mestinya sebagai penunjang aktivitas pariwisata.

Sedangkan Rejuvenation/ Peremanjaan ialah terjadinya perubahan dramatis dalam penggunaan dan pemanfaatan sumber daya pariwisata. Terjadi penciptaan seperangkat atraksi wisata artificial baru atau penggunaan sumber daya alam yang tidak tereksploitasi sebelumnya.

\section{METODE PENELITIAN}

Penelitian ini berlokasi di Desa Pangsan, Kecamtan Petang, Kabupaten Badung. Adapun 
jenis data yang digunakan yaitu data kualitatif berupa gambaran umum desa serta informasi terkait perkembangan desa wisata, sednagkan data kuantitatif berupa jumlah kunjungan maupun akomodasi yang tersedia.

Sumber data yang digunakan adalah sumber data primer dan data sekunder. Sumber data primer yaitu yang bersumber langsung dari informan. Sedangkan data sekunder yaitu yang bersumber dari pihak lain atau bukan dari sumber pertama yang berkaitan dengan penelitian ini.

Teknik pengumpulan data dalam penelitian ini yaitu dengan terjun langsung ke lokasi penelitian dengan mengamati potensi desa wisata, kunjungan wisatawan, dan peran serta dari masyarakat Desa Pangsan dalam pengelolaan Desa Wisata Pangsan. Data yang diperoleh melalui observasi, wawancara mendalam, studi kepustakaan, studi dokumentasi dan angket dianalisis secara deskriptif kualitatif (Sugiyono,2014).

Penentuan informan dilakukan dengan cara purposive sampling. Penelitian ini menggunakan metode deskriptif kualitatif yang yang merupakan data yang disusun secara sistematis terkait perkembangan Desa Wisata Pangsan melalui teori analisis setelah adanya penetapan sebagai desa wisata oleh pemerintah Kabupaten Badung.

\section{HASIL DAN PEMBAHASAN}

Desa Wisata merupakan suatu bentuk integrasi antara interaksi, akomodasi, dan fasilitas pendukung yang disajikan dalam struktur kehidupan masyarakat yang menyatu dengan tata cara dan tradisi yang berlaku. Terlihat pada Desa Pangsan yang telah memiliki struktur kehidupan yang menyatu yang diatur dalam suatu awig-awig desa dan beberapa tradisi unik sesuai dengan ciri khas desa yang sebagian besar merupakan area pertanian. Selain itu, Desa Pangsan memiliki akomodasi seperti adanya home stay dan tempat makan yang masih standar, serta fasilitas pendukung seperti parkir yang khusus disediakan untuk wisatawan berkunjung dan tiga toilet umum untuk wisatawan nantinya.

Tahap Perkembangan desa wisata Pangsan dilihat dari hasil penelitian yang dilakukan dengan analisa Teori Siklus Hidup Destinasi (Destination Lifecycle Model) berada pada tahap Involvement/keterlibatan yakni meningkatnya pengunjung yang mendorong penduduk lokal menawarkan fasilitas secara ekslusif kepada pengunjung. Kontak dengan penduduk lokal tetap tinggi dan beberapa dari mereka mulai menyesuaikan pola sosialnya untuk mengakomodasi perubahan kondisi ekonomi akibat keberadaan wisatawan. Promosi destinasi wisata mulai diinisiasi.

Desa Wisata Pangsan tergolong ke dalam tahap Involvement/ Keterlibatan yang merupakan tahap-tahap awal dalam perkembangan suatu destinasi wisata yang telah melewati tahap Exploration/Eksplorasi yang merupakan tahap pertama.

Beberapa hal yang menyatakan tahap perkembangan Desa Wisata Pangsan berada pada tahap Involvement/Keterlibatan yaitu:

1. Tingkat Kunjungan

Setelah lima tahun penetapan Desa Pangsan sebagai desa wisata di Kabupaten Badung, Desa Wisata Pangsan memeperoleh kunjungan wisatawan dengan adanya beberapa atraksi yang ditampilkan kepada wisatawan.

Tabel 4.1: Jumlah Kunjungan Wisatawan

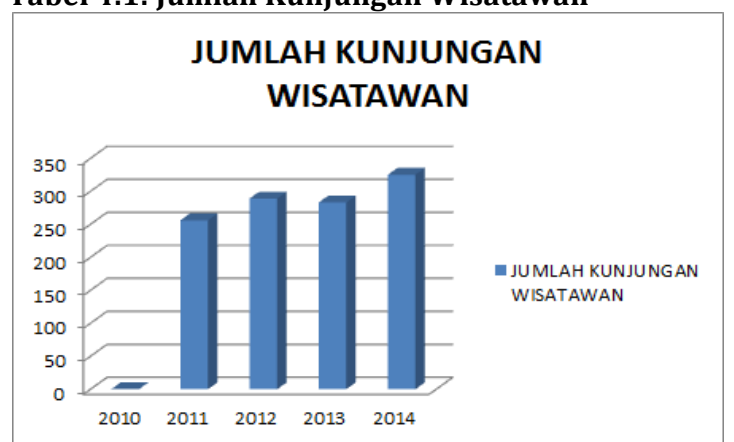

Sumber: Data Base Pengelola/Pokdarwis

Dilihat dari table 4.1, bahwa adanya kunjungan pertahun yang cukup meningkat dari tahun 2010 hingga 2014. Dari jumlah kunjungan tersebut dapat dikatakan cukup kecil dibandingkan dengan beberapa destinasi lainnya di Kabupaten Badung, sehingga terlihat Desa Wisata Pangsan berada pada tahap pertama yaitu exploration yaitu adanya kunjungan yang masih terbatasa atau cukup kecil.

2. Fasilitas

Berbagai usaha-usaha kepariwisataan yang menunjang keberadaan Desa Wisata seperti Usaha Penginapan yang sudah tersedia penginapan atau home stay yang berada 
di rumah warga yang pemiliknya Bp. Nyoman Kitha memiliki tujuh kamar yang bernama Pondok Wisata Campuhan Hilltop Bungalow dan Bp. Wartana yang sedang proses penggarapan penginapan tersebut. Dari adanya usaha pariwisata yang muncul sebagai akomodasi, terlihat bahwa Desa Wisata Pangsan telah berada pada posisi involvement yaitu dengan adanya kunjungan, mendorong masyarakat lokal untuk membuat atau menawarkan fasilitas yang ada seperti akomodasi tersebut.

3. Atraksi

Potensi alam yang secara alami dikembangkan untuk menarik kunjungan wisatatawan seperti adanya sungai disekitar desa yang dimanfaatkan untuk kegiatan rafting dan keindahan alam Desa Pangsan yang dapat menghasilkan beraneka ragam tanaman yang berguna bagi masyarakat sendiri.

Selain itu beberapa tradisi yang unik terdapat di Desa Wisata Pangsan seperti Tradisi Lampat yang merupakan tradisi desa Pangsan yang dilaksanakan pada hari Purnama (satu bulan sekali) di Pura Penataran Agung Desa Pangsan. Tradisi ini dilakukan oleh anak-anak remaja di desa (sekaa truna truni) dengan berkeliling desa untuk mencari atau memetik hasil kebun sebanyak 7 macam tanpa ada larangan oleh pemilik kebun ketika memetik. Tradisi Ngendar yang merupakan tradisi bagi anak-anak usia 5-12 tahun dengan membuat bubur di Pura yang nantinya dibagikan kepada penduduk desa. Tradisi Nyerah Saye yang merupakan tradisi penyerahan tanggung jawab kelian desa dengan upacara adat untuk terus mengingat tanggung jawab yang diemban selaku manusia yang memiliki kuasa di desa.

Selain itu terdapat beberapa atraksi buatan yang ditawarkan pada Desa Wisata Pangsan seperti Trekking. Wisatawan akan berkeliling sepanjang 6 $\mathrm{km}$ jika seluruh area dikelilingi tergantung pilihan dari wisatawan. Cycling, wisatawan akan berkeliling desa menggunakan sepeda dengan melintasi jalan utama saja diarea persawahan dan pemukiman warga sehingga dapat melihat keseharian masyarakat setempat. Serta kegiatan rafting, dengan adanya potensi alam yaitu sungai Ayung juga dimanfaatkan oleh salah satu masyarakatnya dengan menyediakan kegiatan rafting .

4. Keterlibatan/Partisipasi dan Interaksi Partisipasi masyarakat lokal khususnya yang terlihat yaitu masyarakat lokal telah terlibat sebagai pengelola dan anggota pokdarwis, selain itu mulai munculnya homestay yang dibuat oleh masyarakat lokal desa Pangsan dengan fasilitas yang memadai serta adanya usaha rafting oleh masyarakat lokal. Interaksi wisatawan dengan masyarakat lokal, terlihat pada penerimaan wisatawan oleh masyarakat yang langsung dapat berkomunikasi dengan kemampuan berbahasa asing yang cukup baik selama satu hari berada di desa wisata.

5. Promosi

Untuk meningkatkan kunjungan wisatawan, masyarakat melakukan promosi melalui brosur-brosur yang disediakan, serta keikutsertaan Desa Wisata Pangsan dalam kegiatan Festival Budaya Pertanian Kabupaten Badung yang diselenggarakan setiap tahunnya di Jembatan Tukad Bangkung Desa Pelaga Kecamatan Petang. Hal tersebut dapat dijadikan sarana promosi dari pihak masyarakat untuk memperkenalkan destinasi serta produk-produk yang ditawarkan.

6. Dampak

Adapun dampak yang dirasakan bagi masyarakat dengan adanya kegiatan desa wisata seperti, dampak terhadap ekonomi yaitu berupa dampak postif dari adanya desa wisata yaitu dengan terciptanya lapangan kerja yang baru bagi penduduk lokal di bidang pariwisata seperti pemandu saat atraksi dan pelayan pada homestay.

Dampak terhadap social yaitu melalui desa wisata atau pariwisata ini dapat memberikan dampak positif dari segi tingkat pendidikan 
masyarakat, serta masyarakat menjadi lebih memiliki wawasan terkait pariwisata dan meningkatkan kesadaran dengan pentingnya kegiatan desa wisata ini bagi masyarakat lokal. Dampak terhadap budaya berupa dampak positif dari desa wisata dalam hal budaya terlihat pada mulai diminatinya produk-produk tradisional masyarakat berupa hasil kesenian dan kerajinan masyarakat setempat serta melestarikan tradisi Desa Pangsan untuk menarik kunjungan wisatawan. serta adanya dampak terhadap lingkungan yaitu lingkungan akan lebih ditata dan bersih.

\section{SIMPULAN DAN SARAN \\ 1.Simpulan}

Desa Wisata Pangsan merupakan salah satu dari tujuh desa wisata di Kecamatan Petang yang melibatakan masyarakatnya dalam pengelolaan destinasi. Partisipasi masyarakat Desa Pangsan berupa tenaga yang disumbangkan untuk desa wisata seperti memberikan pelayanan pada wisatawan ketika berkunjung, hingga membuat usaha pariwisata untuk menunjang fasilitas seperti adanya home stay dan usaha rafting dari masyarakat desa sendiri yang memanfaatkan sungai di desa Pangsan. Setelah adanya penetapan Desa Pangsan sebagai Desa Wisata, masyarakat menyalurkan ide-idenya yang dapat menjadi penunjang fasilitas desa wisata hingga sekarang.

Berdasarkan hasil temuan penelitian di Desa Wisata Pangsan Kecamatan Petang Kabupaten Badung, tahap perkembangan Desa Wisata Pangsan sebagai destinasi di Kecamatan Petang yaitu pada tahap Involvement/Keterlibatan. Pada tahap ini menunjukan meningkatnya pengunjung yang mendorong penduduk lokal menawarkan fasilitas secara ekslusif kepada pengunjung. Kontak dengan penduduk lokal tetap tinggi dan beberapa dari mereka mulai menyesuaikan pola sosialnya untuk mengakomodasi perubahan kondisi ekonomi akibat keberadaan wisatawan. Promosi destinasi wisata mulai diinisiasi. Dilihat dari jumlah kunjungan yang meningkat namun pertumbuhan yang lambat, didukung dengan atraksi alam, budaya, dan buatan serta fasilitas dari masyarakat seperti penginapan, restoran, serta infrastruktur pendukung. Sedangkan keterlibatan/partisipasi masyarakat diantaranya:

1. Adanya home stay di rumah masyarakat yaitu Pondok Wisata Campuhan Hilltop Bungalow dan satu lagi sedang proses menggarapan untuk dijadikan home stay oleh salah satu masyarakat Desa Pangsan

2. Keikutsertaan masyarakat sebagai pemandu lokal, pelayan pada home stay,rafting, dan atraksi buatan yang disediakan

3. Dalam hal pengelolaan oleh masyarakat lokal dan adanya kelompok POKDARWIS yang anggotanya masyarakat Desa Pangsan

4. Mulai mempromosikan desa wisata melalui brosur untuk meningkatkan kunjungan wisatawan serta keikutsertaan Desa Wisata Pangsan dalam kegiatan Festival Budaya Pertanian Kabupaten Badung

Adanya keterlibatan/ partisipasi masyarakat juga memberikan dampak terhadap ekonomi, social, budaya, serta lingkungan Desa Pangsan.

\section{Saran}

Adapun rekomendasi yang dapat diberikan kepada masyarakat selaku pengelola desa wisata untuk dapat mengembangkan Desa Pangsan dengan menonjolkan daya tarik yang ada di desa, seperti menampilan tradisi desa untuk menarik kunjungan wisatawan. Selain itu, pemerintah juga dapat memberikan fasilitas pendukung dan melakukan pendekatan dengan masyarakat untuk memberikan motivasi bahwa pentingnya mengembangkan desa wisata Pangsan agar lebih dikenal wisatawan yang nantinya dapat memberikan keuntungan bagi masyarakat lokal, seperti membuka lapangan pekerjaan maupun keuntungan ekonomi lainnya. Serta perlu adanya penelitian lebih lanjut bagaimana strategi pengelolaan yang lebih baik, agar Desa Wisata Pangsan lebih diminati oleh wisatawan. Sehingga daya tarik wisata tidak hanya sekedar ditetapkan tanpa ada keberlanjutan. 


\section{Daftar Pustaka:}

Adiguna,Wildan.2013.Kajian Daya Tarik WisataTerkait Perkembangan ObjeK Wisata Goa Pindul.Tugas Akhir S1, Universitas Gadjah Mada

Butler w.2004.The Tourism Area Life Cycle.USA.Cromwell Press

Dinas Pariwisata Badung.2014.Berlibur di Kabupaten Badung Bali. Badung.Dinas Pariwisata Badung

J.Page,Stephen and Don Getz.1997.The Bussines of Rural Tourism International

Perspectives.London.International Thomson Bussines Press

Kadarwati,Atik.2008.Potensi dan Pengembangan Wisata Kota Lama SemarangSebagai Daya Tarik di Semarang.Laporan Akhir,Universitas Sebelas Maret

Peraturan Bupati Nomor 47 Tahun 2010 tentang Ditetapkan Desa Wisata di Kabupaten Badung

Pitana, I Gede.2009.Pengantar Ilmu

Pariwisata.Yogyakarta.Andi

Sugiyono.2014.Metode Penelitian Kuantitatif Kualitatif dan $R \& D$.Bandung.Alfabeta

Suwena,Ketut dan Ngurah Widyatmaja.2010.Pengetahuan Dasar Ilmu Pariwisata.Denpasar.Udayana Pres 